\title{
Proteomic responses to progressive dehydration stress in leaves of chickpea seedlings
}

\author{
Saeedreza Vessal ${ }^{1 *}$, Mohammad Arefian² and Kadambot H. M. Siddique ${ }^{3}$
}

\begin{abstract}
Background: Chickpea is an important food legume crop with high protein levels that is widely grown in rainfed areas prone to drought stress. Using an integrated approach, we describe the relative changes in some physiological parameters and the proteome of a drought-tolerant (MCC537, T) and drought-sensitive (MCC806, S) chickpea genotype.

Results: Under progressive dehydration stress, the T genotype relied on a higher relative leaf water content after 3 and $5 \mathrm{~d}$ (69.7 and 49.3\%) than the $S$ genotype (59.7 and 40.3\%) to maintain photosynthetic activities and improve endurance under stress. This may have been facilitated by greater proline accumulation in the T genotype than the S genotype (14.3 and $11.1 \mu \mathrm{mol} \mathrm{g}{ }^{-1} \mathrm{FW}$ at $5 \mathrm{~d}$, respectively). Moreover, the T genotype had less electrolyte leakage and lower malondialdehyde contents than the $\mathrm{S}$ genotype under dehydration stress, indicating greater membrane stability and thus greater dehydration tolerance. The proteomic analysis further confirmed that, in response to dehydration, the T genotype activated more proteins related to photosynthesis, stress response, protein synthesis and degradation, and gene transcription and signaling than the $S$ genotype. Of the time-point dependent proteins, the largest difference in protein abundance occurred at $5 \mathrm{~d}$, with 29 spots increasing in the T genotype and 30 spots decreasing in the $\mathrm{S}$ genotype. Some of the identified proteins-including RuBisCo, ATP synthase, carbonic anhydrase, psbP domain-containing protein, L-ascorbate peroxidase, 6-phosphogluconate dehydrogenase, elongation factor Tu, zinc metalloprotease FTSH 2, ribonucleoproteins and auxin-binding protein - may play a functional role in drought tolerance in chickpea.
\end{abstract}

Conclusions: This study highlights the significance of genotype- and time-specific proteins associated with dehydration stress and identifies potential resources for molecular drought tolerance improvement in chickpea.

Keywords: Chickpea, Comparative proteomics, Dehydration stress, Proline

\section{Background}

Plants are frequently exposed to abiotic stress such as dehydration in their natural habitats, which causes significant losses in yield and quality worldwide [1]. Climate changes are estimated to progressively increase the frequency, severity, and duration of drought periods [2].

\footnotetext{
* Correspondence: vessal@um.ac.ir

${ }^{1}$ Research Center for Plant Sciences, Ferdowsi University of Mashhad, Mashhad, Iran

Full list of author information is available at the end of the article
}

To meet the needs of the growing world population, stabilizing or increasing yield potential under drought stress is imperative [3]. Plants respond to stress by reprogramming their proteins to ensure a steady-state of vital metabolic processes [4]. To this end, identifying novel proteins and responsive pathways involved in stress adaptation will provide new insights and enable direct genetic manipulations to improve climate-resistant crops.

Chickpea (Cicer arietinum L.) ranks third in terms of production and second in area, among the world's food 
legume crops [5, 6]. Regardless of human dietary and health benefits, chickpea is effective at fixing atmospheric nitrogen and enriching soil fertility. Worldwide, chickpea yields more than 11 million tons from a cultivation area of $\sim 12$ million hectares [7]. Improvements in chickpea production have been slow, mainly because it is grown in rainfed areas where terminal drought is a major factor affecting its yield potential [8]. Although drought tolerance in chickpea is relatively higher than other cool-season legumes [9], seed yield losses due to drought varies from 30 to $100 \%[10,11]$ depending on the type of drought and genotype.

Water stress reduces plant growth through physiological, biochemical, and molecular processes, including hormone induction, photosynthesis, respiration, kinase cascade signaling, ion uptake, carbohydrate and osmolyte metabolism, nitrogen assimilation, and amino acid metabolism. These processes can be analyzed using genes or their related proteins, but proteins play a critical role as they directly participate in plant responses to stress [12, 13]. Faster signal acquisition and better responses to water stress could be used to select or breed new plant genotypes with increased drought resistance. Hence, a precise and comparative analysis of the proteome in drought-sensitive and drought-tolerant plant genotypes is a fundamental step for understanding the mechanisms of stress adaptation physiology and wateruse efficiency [14]. Wheat mutant plants exposed to drought stress had superior drought tolerance due to well-preserved leaf water balance, sustained membrane integrity, mobilized antioxidant defense and osmoregulation, and less affected photosynthetic activity [15-17].

To understand the molecular mechanisms responsible for dehydration stress, the events occurring in key functional molecules such as proteins need to be described. Although transcriptome profiling is a widely used technique to identify genes that are responsive to dehydration, there is far less evidence for proteins as functional products. Poor to moderate correlations between mRNA levels and the corresponding proteins have been reported in Arabidopsis [18]. Indeed, the role of genes in drought tolerance requires an understanding of their function at the protein level [19]. In recent years, several proteomic studies on dehydration have focused on the extracellular matrix $[19,20]$, cell nuclear [21-23], and seed germination [24] proteomes of chickpea seedlings. Proteome changes in chickpea have been investigated under other abiotic stresses, such as heat [25], salinity $[26,27]$, and abscisic acid [28]. The extracellular matrix (ECM) is a dynamic structure that includes important signaling components for front-line defense. An LC-ESIMS/MS analysis identified dehydration-responsive proteins in chickpea's ECM and revealed genotype-specific expression of proteins. It was also reported that cell wall restructuring and homeostasis of reactive oxygen species (ROS) are mainly influenced by a dehydrationadaptation mechanism [19, 20]. Among 4832 identified nuclear proteins of chickpea under drought stress, 299 unique phosphoproteins were involved in gene expression, protein degradation, and regulation of flowering time and the circadian clock [28]. Vessal et al. (2012) [24] investigated the germination of chickpea genotypes under limited water supply using 2-DE and MALDI-TOF/TOF LC-MS/MS analyses. Of 65 identified proteins, LEA and HSP proteins and proteins associated with ROS metabolism and the TCA cycle were identified as important pathways for coping with chickpea germination under water-limited conditions.

It is well-documented that chickpea growth and yields are highly significantly challenged by dehydration stress, with losses of up to $40-50 \%$ in crop productivity, mainly in areas lacking satisfactory and constant rainfall [29]. Chickpea is mainly grown in arid and semiarid areas, such as Iran, on stored soil moisture from the rainy season (winter or early spring); terminal or intermittent drought stress is a major constraint for productivity [8]. Consequently, breeding programs are needed to develop chickpea lines with higher water-use efficiency. We undertook a comparative analysis of drought-responsive proteins in a drought-tolerant and drought-sensitive chickpea genotype. Based on trait classifications reported by our colleagues [26, 30], MCC537 and MCC806 were considered as the most drought-tolerant and droughtsensitive genotypes, respectively, among 150 chickpea genotypes. Some key physiological and biochemical parameters have been evaluated in these contrasting genotypes, including root and shoot fresh and dry weights, relative water content, proline, chlorophyll, carotenoid and MDA contents, antioxidant activity (CAT, GR, SOD, APX and DPPH), and sodium and potassium concentrations in roots and shoots. In the current study, along with some physiological assessments, proteome alterations in these genotypes under drought stress were explored using two-dimensional gel electrophoresis coupled with mass spectrometry to identify 34 differentially modulated spots.

To our knowledge, there are no reports on total proteome changes in chickpea leaves exposed to dehydration stress. The lack of sufficient genomic information at the functional protein level prompted us to evaluate early physiological responses and undertake a comprehensive proteomic analysis of dehydration stress responses in two extreme chickpea genotypes. We identified some novel dehydration stress-responsive leaf proteins, differentially expressed in chickpea seedlings exposed to a progressive stress situation. 


\section{Methods}

\section{Plant material and stress treatment}

We used MCC537 (T) and MCC806 (S) as droughttolerant and drought-sensitive chickpea genotypes, respectively, based on previous reports [26, 30]. Seeds of genotypes were acquired from the Research Center for Plant Sciences, Ferdowsi University of Mashhad, Iran. The seeds were surface sterilized in $3 \%(\mathrm{w} / \mathrm{v})$ sodium hypochlorite and $70 \%$ ethanol for $1 \mathrm{~min}$, followed by five washes with sterile water. The sterilized seeds were germinated on moistened Whatman filter paper in $10 \mathrm{~cm}$ diameter Petri dishes at $25 \pm 1{ }^{\circ} \mathrm{C}$ for $48 \mathrm{~h}$ in a germinator. Four uniformly germinated seeds were transferred to $2 \mathrm{~L}$ pots containing loam soil and sand $(2: 1, \mathrm{w} / \mathrm{w})$ in a greenhouse set at $28 / 20 \pm 3{ }^{\circ} \mathrm{C}$ (day/night), $60 \pm 5 \%$ relative humidity, and $\mathrm{a} \sim 16 \mathrm{~h}$ photoperiod. After 1 week, each pot was thinned to two seedlings and irrigated with $150 \mathrm{~mL}$ of water daily to maintain soil water content at $\sim 40 \%$. At 28 days after sowing, the seedlings in the stress treatment were subjected to gradual, progressive dehydration by withdrawing water and allowing evapotranspiration; the control plants were watered normally. The middle leaves of each seedling were harvested after 1,3 , and $5 \mathrm{~d}$ of dehydration exposure for each genotype. All treatments were conducted in triplicate.

\section{Physiological analysis}

The relative water content (RWC) of leaf tissue was determined using the following equation: RWC $(\%)=[(\mathrm{FW}$ $-\mathrm{DW}) /(\mathrm{TW}-\mathrm{DW})] \times 100$, where FW is fresh weight, DW is dry weight, and TW is turgid weight [31].

Electrolyte leakage (EL) was determined by estimating the leaching of ions from leaves into distilled water [32]. Briefly, $0.1 \mathrm{~g}$ leaves were placed in $10 \mathrm{~mL}$ distilled water in a Falcon tube in two sets, the first at $40{ }^{\circ} \mathrm{C}$ for $30 \mathrm{~min}$ and the second at $100{ }^{\circ} \mathrm{C}$ for $10 \mathrm{~min}$ in a water bath, before recording conductivity using EC meter $(\mathrm{C} 1$ and $\mathrm{C} 2$, respectively). The EL (\%) was calculated as $(\mathrm{C} 1 / \mathrm{C} 2) \times 100$.

Free proline content was determined using a colorimetric assay using the method developed by [33]. Leaf tissue $(0.2 \mathrm{~g})$ was homogenized in $4 \mathrm{~mL} 3 \%$ aqueous sulfosalicylic acid and then centrifuged at $9000 \mathrm{~g}$ for 10 min. The supernatant was mixed with ninhydrin and glacial acetic acid in equal ratio, then boiled at $100{ }^{\circ} \mathrm{C}$ for $1 \mathrm{~h}$ and the absorbance read at $520 \mathrm{~nm}$. The proline concentration was measured using the standard curve and expressed as $\mu \mathrm{mol}$ proline $\mathrm{g}^{-1}$ FW.

Membrane lipid peroxidation was determined from malondialdehyde (MDA) accumulation using the procedure of Heath and Packer (1968) [34]. Fresh leaf tissue $(0.2 \mathrm{~g})$ was ground in $0.1 \%$ trichloroacetic acid (TCA) and centrifuged at $9000 \mathrm{~g}$ for $10 \mathrm{~min}$. The supernatant was mixed with $20 \%$ TCA, containing $0.5 \%$ thiobarbituric acid in a $1: 4(\mathrm{v} / \mathrm{v})$ ratio and heated at $90{ }^{\circ} \mathrm{C}$ for 30 min. Absorbance (A) was recorded at $532 \mathrm{~mm}$ and 600 $\mathrm{nm}$, and MDA calculated according to MDA ( $\mu \mathrm{mol} \mathrm{g} \mathrm{g}^{-1}$ $\mathrm{FW})=\left(\mathrm{A}_{532}-\mathrm{A}_{600}\right) / 1.55 \times 10^{-5} \mathrm{M} \mathrm{cm} \times \mathrm{b}$.

\section{Sample preparation and two-dimensional electrophoresis (2-DE)}

To identify proteins involved in drought tolerance, leaf samples were ground in liquid nitrogen to a fine powder and total protein extracts prepared using the method of Goggin et al. (2011) [35]. Briefly, the finely ground leaf samples $(1 \mathrm{~g})$ were suspended in extraction buffer containing $8 \mathrm{M}$ urea, $2 \%$ (v/v) Triton X-100, $25 \mathrm{mM}$ DTT, and $2 \%(\mathrm{w} / \mathrm{v}) \mathrm{CHAPS}$ and held at $-4{ }^{\circ} \mathrm{C}$ for $15 \mathrm{~min}$. After centrifugation at $12,000 \mathrm{~g}$ for $10 \mathrm{~min}$, the pellets were air-dried before being dissolved in $9 \mathrm{~mL}$ chilled acetone containing $3 \% \mathrm{TCA}$ and incubated at $-80^{\circ} \mathrm{C}$ for $1 \mathrm{~h}$. Soluble chlorophyll and other impurities were removed by centrifugation at $14,000 \mathrm{~g}$ for $30 \mathrm{~min}$; the pelleted protein was dissolved in minimal isoelectric focusing (IEF) buffer contained $8 \mathrm{M}$ urea, $4 \%(\mathrm{w} / \mathrm{v})$ CHAPS, $65 \mathrm{mM} \mathrm{DTT}$, and 2\% (v/v) immobilized $\mathrm{pH}$ gradient (IPG) buffer $\mathrm{pH} 4-7$. The protein concentration of each sample was determined using the method of MM Bradford [36].

The solubilized proteins $(400 \mu \mathrm{g})$ were used to rehydrate $17 \mathrm{~cm}$ IPG strips at $\mathrm{pH} 4-7$ (BioRad). The proteins were covered with mineral oil to avoid urea crystallization and rehydrated for $16 \mathrm{~h}$ at room temperature. The strips were subjected to electrophoresis for $38 \mathrm{kV} . \mathrm{h}$ using the PROTEAN IEF Cell System (BioRad, USA) before equilibration in $15 \mathrm{~mL}$ equilibration solution (6 M urea, $50 \mathrm{mM}$ Tris $\mathrm{pH} 8.8,30 \%[\mathrm{v} / \mathrm{v}]$ glycerol, 2\% [w/v] SDS and 0.002\% [w/v] bromophenol blue) containing $65 \mathrm{mM}$ DTT, and $135 \mathrm{mM}$ iodoacetamide for $15 \mathrm{~min}$ for each equilibration solution. Protein separation in the second dimension was performed with SDS-PAGE gels containing $12.5 \%(\mathrm{w} / \mathrm{v})$ polyacrylamide on PROTEAN II MultiCell (BioRad, USA).

\section{Gel staining, imaging, and data analysis}

The separated proteins were visualized using 0.12\% (w/ v) Coomassie Brilliant Blue G-250 staining solution containing $10 \%$ orthophosphoric acid (v/v) and 10\% ammonium sulfate $(\mathrm{w} / \mathrm{v})$ as described by Candiano et al. (2004) [37]. The stained gels were scanned using a GS800 Calibrated Densitometer (BioRad) at a resolution of 600 dpi. Gel images were analyzed using ImageMaster ${ }^{\text {тм }}$ 2D Platinum Version 6.0 (GE Healthcare Bio-Science). The experimental molecular mass $\left(M_{\mathrm{r}}\right)$ and isoelectric point $(\mathrm{p} I)$ of the proteins were determined using standard protein markers (Sigma, USA) and the relative migration of protein spots on IPG strips, respectively. The analysis was based on percent volumes, and significant differences $(p \leq 0.05)$ in the expression of the spot were 
calculated using one-way analysis of variance and Duncan's multiple range test if the mean abundance varied more than two-fold.

\section{Protein identification}

Protein spots were identified by liquid chromatography coupled with tandem mass spectrometry (LC-MS/MS) analysis, as described by Bringans et al. (2008) [38], at Proteomics International, Nedlands, Western Australia, using an Agilent 1260 Infinity HPLC system (Agilent) coupled to an Agilent 1260 Chipcube Nanospray interface (Agilent) on an Agilent 6540 mass spectrometer (Agilent). The raw spectral data were processed into MASCOT Generic File format, and the MS/MS ion search was performed using MASCOT (http://www. matrixscience.com) to search the NCBInr database and using Viridiplantae (green plants) as the taxonomy. The parameters for the search were: an MS/MS tolerance of $\pm 0.2 \mathrm{Da}$, one missed cleavage site, enzyme of trypsin, variable modifications of carbamidomethyl, peptide tolerance of $\pm 0.2 \mathrm{Da}$, peptide charge of $2+3+4+$, monoisotopic, and ESITRAP instrument. The score threshold to achieve $p<0.05$ was set by the MASCOT algorithm, which is based on the size of the database used in the search. In the case of multiple significant hits for a protein, only the highest scoring hit is listed in Table 1. Details on the theoretical and experimental molecular weights and isoelectric points, percent coverage, and accession number for proteins identified with a single peptide are listed in Table 1 . The function of the identified proteins was analyzed in terms of the metabolic role of the identified protein in response to stress by searching the NCBI and UniProt databases and literature reviews [39].

\section{Statistical analysis}

The results are presented as means \pm SE. To identify statistically significant differences between means, one-way ANOVA and Duncan's multiple range test were performed with a $5 \%$ level of significance using SPSS software (ver. 24).

\section{Results}

Dehydration stress responses of chickpea seedlings at the physiological level

Physiological responses to dehydration stress were monitored in 28-day-old seedlings of the selected tolerant $(\mathrm{T})$ and sensitive (S) chickpea genotype to identify differences in drought resistance. Changes in EL, as a biomarker of membrane integrity [40], were measured over 5 days of dehydration stress. The EL index increased moderately from $1 \mathrm{~d}$ to $3 \mathrm{~d}$ of stress in both genotypes, relative to the control, with a significant increase from 3 $\mathrm{d}$ to $5 \mathrm{~d}$ of stress, especially in the $\mathrm{S}$ genotype (Fig. $1 \mathrm{~b}$ ).
Malondialdehyde levels declined after the first day of stress, relative to the controls, then increased significantly up to $5 \mathrm{~d}$ of dehydration stress, more so in the $\mathrm{S}$ genotype. After 5 days of dehydration stress, leaf RWC had declined by 43 and $31 \%$ in the $\mathrm{S}$ and $\mathrm{T}$ genotypes, respectively, relative to their respective controls, and was accompanied by increasing proline contents. After $5 \mathrm{~d}$ of dehydration stress, the $\mathrm{S}$ and $\mathrm{T}$ genotypes had 5.3- and 6.2-fold higher proline contents, respectively, than the controls (Fig. 1b).

\section{Proteome changes in response to dehydration stress in two chickpea genotypes}

This study detected 1184 reproducible protein spots, of which 237 had significant changes in abundance during the stress, relative to the controls. Protein spots with absolute variation ( $\geq 1.5$-fold, $p<0.05$ ) in the quantitative image analysis were considered to have changed significantly after dehydration stress and analyzed further. Thirty-four proteins were characterized as differentially expressed proteins (DEPs) between the two genotypes in response to dehydration stress (Fig. 2). The $\mathrm{T}$ genotype generally had more up-regulated proteins than the $\mathrm{S}$ genotype at each time-point (Fig. 3).

Genotype- and stress time-point dependent DEP spots were examined in a Venn diagram (Fig. 4a). The two genotypes differed in protein expression in response to dehydration; the $\mathrm{T}$ genotype responded to dehydration by increasing up-regulated spot proteins ( 29 spots at $5 \mathrm{~d}$ ), the $\mathrm{S}$ genotype had more down-regulated proteins (30 spots at $5 \mathrm{~d}$ ). Both genotypes had similar expression patterns of some spots in response to dehydration, with 16 up-regulated spots and five down-regulated spots (Fig. 3a).

Figure 3b identifies the DEPs shared by, or specific to, each time-point. Both genotypes had the largest difference in abundance after $5 \mathrm{~d}$ of stress. Across all timepoints, the $\mathrm{T}$ genotype shared 20 up-regulated spots, while the $S$ genotype only shared nine down-regulated spots. Of the time-point dependent spots, the $\mathrm{S}$ genotype uniquely regulated nine, five, and 14 spots, and T genotype regulated four, zero, and five spots after 1, 3, and 5 $\mathrm{d}$ of dehydration stress, respectively (Fig. 3b).

Table 1 summarizes the proteins identified by LC-MS/ MS, including names (where applicable), MASCOT score, percent coverage, theoretical/experimental $\mathrm{p} I$ and $M r$, and accession numbers. Most of the identified proteins were strictly matched to chickpea (Cicer arietinum L.) with a high score and decent sequence coverage. The proteins were grouped into six categories by putative function. Most were involved in photosynthesis (44\%), stress response (17\%), and protein synthesis and degradation (14\%) (Fig. 4). Of the identified proteins (34 protein spots), some were critical for functional responses 
Table 1 Proteins from drought-treated chickpea with $\geq 1.5$-fold alteration, relative to control values, identified by LC-MS/MS analysis and Mascot database search

\begin{tabular}{|c|c|c|c|c|c|c|c|}
\hline Spot no. ${ }^{a}$ & Protein identity & Species $^{b}$ & Coverage $(\%)^{c}$ & $\begin{array}{l}\text { MASCOT } \\
\text { score }^{d}\end{array}$ & $\mathrm{TM}_{\mathbf{r}} / \mathrm{EM}_{\mathbf{r}}{ }^{\mathrm{e}}$ & Tpl/Eplf & Acc. No. ${ }^{g}$ \\
\hline & Photosynthesis and photorespiration & & & & & & \\
\hline 3 & $\begin{array}{l}\text { RuBisCO large subunit-binding protein } \\
\text { subunit beta }\end{array}$ & Cicer arietinum & 44 & 1137 & $62.9 / 59.2$ & $5.85 / 5.53$ & XP_012567814.1 \\
\hline 59 & $\begin{array}{l}\text { Probable ribose-5-phosphate isomerase 3, } \\
\text { chloroplastic }\end{array}$ & Cicer arietinum & 29 & 654 & $30.5 / 21.7$ & $6.00 / 4.88$ & XP_004494688.1 \\
\hline 66 & $\begin{array}{l}\text { Ribulose-bisphosphate carboxylase large } \\
\text { subunit, partial }\end{array}$ & Salix bebbiana & 18 & 55 & $23.5 / 14.5$ & $5.61 / 4.94$ & AlG57943.1 \\
\hline 7 & $\begin{array}{l}\text { Glycine dehydrogenase (decarboxylating), } \\
\text { mitochondrial }\end{array}$ & Cicer arietinum & 26 & 633 & $115.3 / 60.2$ & $7.99 / 6.43$ & XP_004498896.2 \\
\hline 33 & ATP synthase subunit beta, chloroplastic & Cicer arietinum & 39 & 585 & $52.9 / 28.7$ & $5.16 / 4.99$ & B5LMK9 \\
\hline 56 & ATP synthase subunit alpha, chloroplastic & Cicer arietinum & 54 & 321 & $19.4 / 21.5$ & $5.05 / 5.16$ & B5LMN1 \\
\hline 38 & $\begin{array}{l}\text { Fructose-bisphosphate aldolase } 1, \\
\text { chloroplastic }\end{array}$ & Cicer arietinum & 21 & 1376 & $43.2 / 33.5$ & $6.28 / 5.98$ & XP_004507507.1 \\
\hline 45 & $\begin{array}{l}\text { Carbonic anhydrase, chloroplastic } \\
\text { isoform X2 }\end{array}$ & Cicer arietinum & 19 & 409 & $35.8 / 22.3$ & $6.61 / 6.66$ & XP_004489275.1 \\
\hline 49 & $\begin{array}{l}\text { psbP domain-containing protein } 1 \text {, } \\
\text { chloroplastic }\end{array}$ & Cicer arietinum & 65 & 643 & $28.6 / 20.5$ & $8.89 / 5.79$ & XP_004494530.1 \\
\hline 22 & $\begin{array}{l}\text { ATP synthase beta subunit, partial } \\
\text { (chloroplast) }\end{array}$ & Eucryphia lucida & 50 & 655 & $51.8 / 40.2$ & $5.20 / 5.38$ & AAK72764.1 \\
\hline 32 & Phosphoribulokinase & Erythranthe guttata & 13 & 148 & $45.5 / 33.1$ & $5.86 / 5.20$ & A0A022QP63 \\
\hline 50 & $\begin{array}{l}\text { Chlorophyll a-b binding protein 3, } \\
\text { chloroplastic }\end{array}$ & Cicer arietinum & 22 & 511 & $29.4 / 20.7$ & $6.32 / 5.56$ & XP_004491629.1 \\
\hline 57 & $\begin{array}{l}\text { Oxygen-evolving enhancer protein } 2, \\
\text { chloroplastic }\end{array}$ & Cicer arietinum & 29 & 721 & $28.7 / 19.0$ & $5.65 / 5.55$ & XP_004499534.1 \\
\hline 62 & $\begin{array}{l}\text { Oxygen-evolving enhancer protein } 1 \text {, } \\
\text { chloroplastic }\end{array}$ & Cicer arietinum & 45 & 679 & $34.9 / 19.0$ & $6.24 / 4.83$ & XP_004509219.1 \\
\hline 67 & $\begin{array}{l}\text { Oxygen-evolving enhancer protein } 2 \text {, } \\
\text { chloroplastic }\end{array}$ & Cicer arietinum & 30 & 643 & $28.7 / 14.2$ & $6.90 / 5.02$ & XP_004499534.1 \\
\hline \multirow[t]{2}{*}{73} & $\begin{array}{l}\text { Oxygen-evolving enhancer protein } 2, \\
\text { chloroplastic }\end{array}$ & Cicer arietinum & 16 & 117 & $28.7 / 9.25$ & $6.90 / 4.72$ & XP_004499534.1 \\
\hline & Stress responsive & & & & & & \\
\hline 11 & Heat shock protein 70 & $\begin{array}{l}\text { Chrysanthemum } \\
\text { morifolium }\end{array}$ & 13 & 265 & $70.8 / 42.2$ & $5.12 / 4.86$ & A0A0A1HAD2 \\
\hline 41 & L-ascorbate peroxidase, cytosolic & Cicer arietinum & 37 & 243 & $27.1 / 23.2$ & $5.65 / 5.94$ & XP_004505943.1 \\
\hline 51 & L-ascorbate peroxidase, cytosolic & Cicer arietinum & 57 & 781 & $27.1 / 20.75$ & $5.65 / 5.36$ & XP_004505943.1 \\
\hline 42 & Glutathione s-transferase & Cicer arietinum & 34 & 270 & $25.6 / 21.8$ & $6.04 / 6.12$ & AOAOX9LENO \\
\hline 77 & Superoxide dismutase [Cu-Zn] & Solanum chacoense & 15 & 1057 & $22.4 / 14.5$ & $6.08 / 5.96$ & AOAOVOHK97 \\
\hline \multirow[t]{2}{*}{81} & Cold shock protein & Cicer arietinum & 31 & 1497 & 19.2/18.5 & $6.29 / 6.55$ & A0A088FZS5 \\
\hline & Protein synthesis and degradation & & & & & & \\
\hline 13 & Elongation factor Tu, mitochondrial & Cicer arietinum & 30 & 272 & $49.1 / 40.2$ & $6.58 / 6.44$ & XP_004493639.2 \\
\hline 17 & $\begin{array}{l}\text { Peptidyl-prolyl cis-trans isomerase } \\
\text { CYP38, chloroplastic }\end{array}$ & Cicer arietinum & 9 & 82 & $50.1 / 39.5$ & $5.12 / 4.68$ & XP_004489294.1 \\
\hline 10 & $\begin{array}{l}\text { Uncharacterized protein LOC101507383, } \\
\text { partial, homoluguse with protein } \\
\text { disulfide isomerase (query coverage 99\%) }\end{array}$ & Cicer arietinum & 15 & 152 & $42.7 / 46.2$ & $4.83 / 4.81$ & XP_004495295.1 \\
\hline 5 & ATP-dependent zinc metalloprotease FTSH 2 & Cicer arietinum & 7 & 88 & $74.7 / 62.7$ & $5.60 / 5.34$ & XP_004504668.1 \\
\hline \multirow[t]{2}{*}{8} & Ubiquitin receptor RAD23d-like & Cicer arietinum & 10 & 55 & $40.3 / 33.7$ & $4.39 / 4.53$ & XP_004489115.1 \\
\hline & Gene transcription & & & & & & \\
\hline 37 & $33 \mathrm{kDa}$ ribonucleoprotein, chloroplastic & Glycine soja & 3 & 66 & $30.4 / 31.5$ & $8.67 / 4.98$ & A0A0B2SU82 \\
\hline
\end{tabular}


Table 1 Proteins from drought-treated chickpea with $\geq 1.5$-fold alteration, relative to control values, identified by LC-MS/MS analysis and Mascot database search (Continued)

\begin{tabular}{|c|c|c|c|c|c|c|c|}
\hline Spot no. ${ }^{a}$ & Protein identity & Species $^{\mathrm{b}}$ & Coverage $(\%)^{c}$ & $\begin{array}{l}\text { MASCOT } \\
\text { score }^{d}\end{array}$ & $\mathrm{TM}_{\mathbf{r}} / \mathrm{EM}_{\mathbf{r}}^{\mathrm{e}}$ & Tpl/Eplf & Acc. No. ${ }^{g}$ \\
\hline 61 & $28 \mathrm{kDa}$ ribonucleoprotein, chloroplastic & Cicer arietinum & 26 & 642 & $29.8 / 24.5$ & $4.74 / 4.64$ & XP_012570426.1 \\
\hline 54 & $29 \mathrm{kDa}$ ribonucleoprotein $\mathrm{A}$, chloroplastic & Cicer arietinum & 16 & 110 & $30.7 / 23.2$ & $5.36 / 4.83$ & XP_004497514.1 \\
\hline \multirow[t]{2}{*}{76} & $\begin{array}{l}\text { U3 small nucleolar ribonucleoprotein protein } \\
\text { MPP10-like isoform }\end{array}$ & Malus domestica & 1 & 61 & $62.3 / 13.2$ & $4.5 / 5.6$ & XP_008367517.1 \\
\hline & Signaling & & & & & & \\
\hline 47 & Auxin-binding protein ABP19a-like & Cicer arietinum & 28 & 569 & $21.9 / 20.7$ & $6.95 / 6.91$ & XP_004513480.1 \\
\hline \multirow[t]{2}{*}{80} & $\begin{array}{l}\text { Low molecular weight phosphotyrosine } \\
\text { protein phosphatase }\end{array}$ & Cicer arietinum & 12 & 287 & $27.1 / 17.7$ & $7.62 / 5.9$ & XP_004506147.1 \\
\hline & Other & & & & & & \\
\hline 44 & Tropinone reductase homolog At5g06060-like & Cicer arietinum & 27 & 250 & $28.5 / 22.5$ & $6.43 / 6.66$ & XP_004492175.1 \\
\hline 9 & COBW domain-containing protein & Cicer arietinum & 39 & 265 & $50.8 / 48.5$ & $5.81 / 4.79$ & XP_004497313.1 \\
\hline 15 & $\begin{array}{l}\text { 6-phosphogluconate dehydrogenase, } \\
\text { decarboxylating } 3\end{array}$ & Cicer arietinum & 43 & 524 & $53.6 / 47.2$ & $5.88 / 5.99$ & XP_004491970.2 \\
\hline
\end{tabular}

${ }^{a}$ Numbering corresponds to the 2-DE gel in Fig. 2a

${ }^{b}$ Species name that the identified proteins is obtained via the MASCOT software from the NCBI database

c Sequence coverage percentage of assigned peptides to the predicted protein

${ }^{d}$ Score probability for the entire protein, obtained by Mascot search engine

e TMr and EMr are theoretical molecular mass and experimental molecular mass, respectively

${ }^{\mathrm{f}} \mathrm{Tp} /$ and Ep/ are theoretical isoelectric point and experimental isoelectric point, respectively

${ }^{g}$ Corresponding gene identification number in GenBank

to stress and also had differential expression between the two genotypes, including ATP synthase, RuBisCo, psbP domain-containing protein, carbonic anhydrase, Lascorbate peroxidase, elongation factor $\mathrm{Tu}$ and 6phosphogluconate dehydrogenase (Fig. 5). In most of these critical proteins, differences in abundance increased with stress duration.

\section{Discussion}

Plants reduce water loss under drought stress by closing stomata, which reduces $\mathrm{CO}_{2}$ uptake and decreases photosynthetic efficiency. In this condition, excess energy excitation occurs, which subsequently produces ROS and methylglyoxal that negatively affect protein, lipid, and DNA function. To cope with this, plants resort to adaptive strategies at the physiological and molecular levels, including repair and detoxification, especially through specific-protein functions [41]. These events often vary among genotypes of a specific plant speciesthese differences can offer valuable perceptions for developing strategies for crop improvement. Most of the research on chickpea drought stress has focused on physiological, genome, and transcript methods [42-46]. However, as drought stress impacts actively on proteinrelated processes such as synthesis and degradation, proteomic studies of drought stress could significantly improve our insight into its repercussions at a functional level. Therefore, the current study characterized proteins to reveal genotype-specific variations in the leaf proteome in response to drought stress in contrasting chickpea genotypes, which led to the final characterization of 34 drought stress-induced DEPs. The largest difference in protein abundance across all timepoints occurred after $5 \mathrm{~d}$ of stress in both genotypes, when 29 protein spots were up-regulated in the $\mathrm{T}$ genotype. Comparative proteomics revealed genotype-specific and drought stress expression of proteins involved in a variety of cellular functions, which may offer some likely candidates for increasing tolerance to drought stress in chickpea. The findings suggest that the up-regulated proteins, especially those in the $\mathrm{T}$ genotype at $5 \mathrm{~d}$ including ATP synthase subunits, psbP domain-containing protein, carbonic anhydrase, RuBisCo subunits, elongation factor $\mathrm{Tu}$ and disulfide isomerase., are associated with important processes such as photosynthesis, protein metabolism, and signaling, which included.

The main source of plant biomass is photosynthesis, which influences potential crop yield and is often sensitive to drought stress; hence, it is a priority for crop breeding programs. In the leaf quantitative proteomic analyses, $44 \%$ of the proteins whose abundance changed significantly in response to dehydration were associated with photosynthesis and photorespiration (Fig. 4 and Table 1). Diverse changes in these proteins have been reported in other plant species under salt stress [47] and heat stress [25]. Six of the identified proteins are involved in light-harvesting complexes (Table 1): psbP domain-containing protein 1 (spot 49), chlorophyll a-b binding protein 3 (spot 50), and oxygen-evolving enhancer protein1, 2 and 3 (spots 62, 57, 67 and 73). 

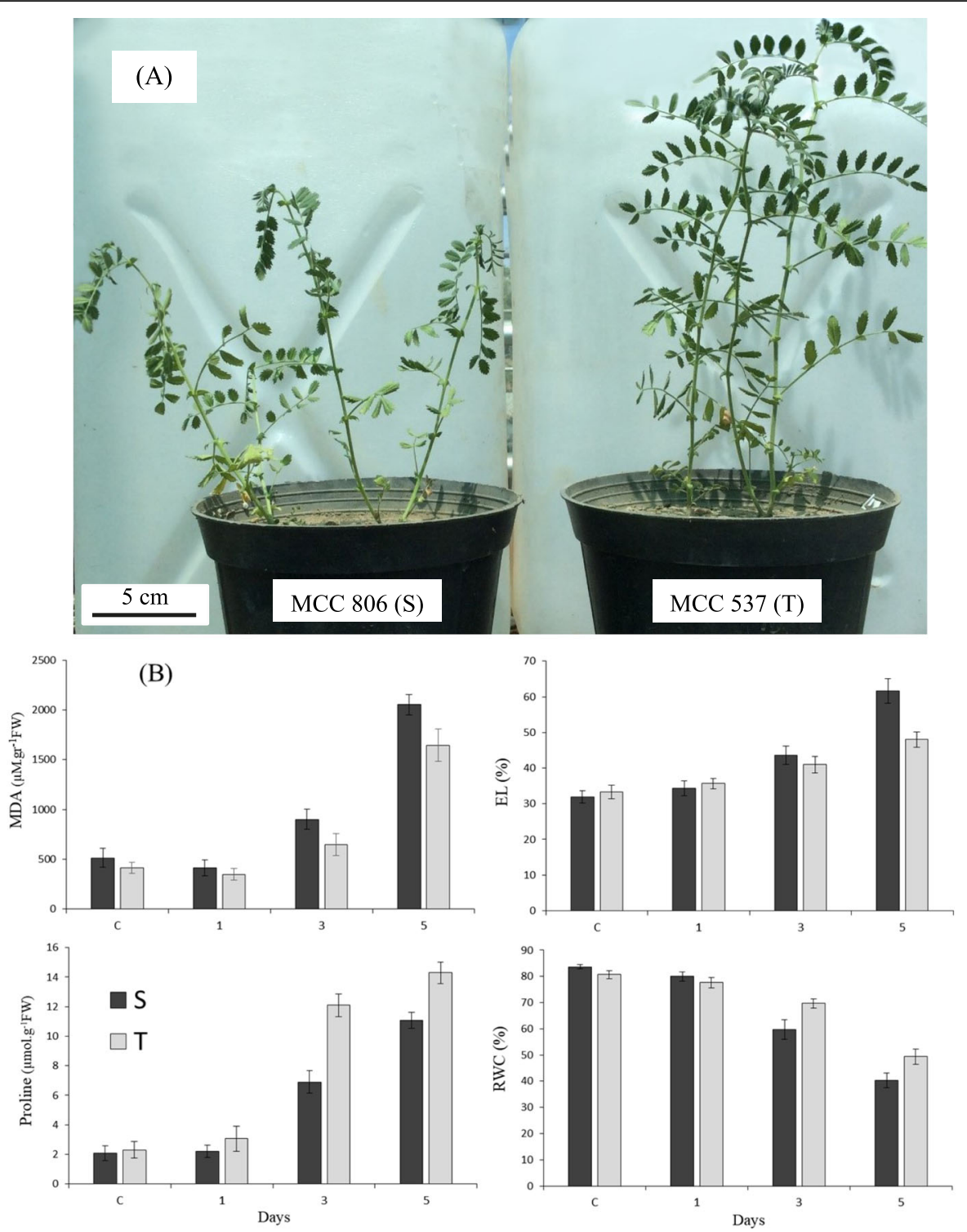

Fig. 1 a Morphological response of 28-day-old chickpea seedlings to progressive dehydration stress for five days. b Physiological changes in seedlings of drought-tolerant (MCC537, T) and drought-sensitive (MCC806, S) chickpea genotypes after 1, 3 and 5 days of dehydration treatment, relative to the control (C), including malondialdehyde (MDA), electrolyte leakage (EL), proline, and relative water content (RWC) of leaves. Error bars indicate the standard error of three biological replicates

The superfamily of chlorophyll a-b binding proteins is associated with photosystem I (PSI) or photosystem II (PSII) [48]. In this study, the psbP domain-containing protein (Fig. 5; spot 49) and chlorophyll a-b binding protein (spot 50) were up-regulated in the $\mathrm{T}$ genotype, possibly because dehydration stress increased photosynthesis more in the $\mathrm{T}$ genotype than the $\mathrm{S}$ genotype. These proteins provide energy to reduce $\mathrm{NADP}^{+}$to NADPH in PSI. The accumulation of proteins associated with light-harvesting complexes in response to drought stress may prevent or reduce light stress-induced damage [49]. Differences between genotypes in the expression of the chlorophyll a-b binding protein likely reflect the redox state of plastoquinone [50]; however, this mechanism should be explored to elucidate its role in chickpea drought tolerance. Consistent with our findings, chlorophyll a-b binding proteins were expressed in response to stress in Arabidopsis [51] and salt-treated Spinacia oleracea [52], and are required for efficient repair of PSII photodamage.

The ATP synthase function is directly related to photosynthesis as it transfers protons through thylakoid membranes. The response of ATP synthase to salinity depends on plant species, genotype, and the duration and severity of stress [53]. All ATP synthase subunits 

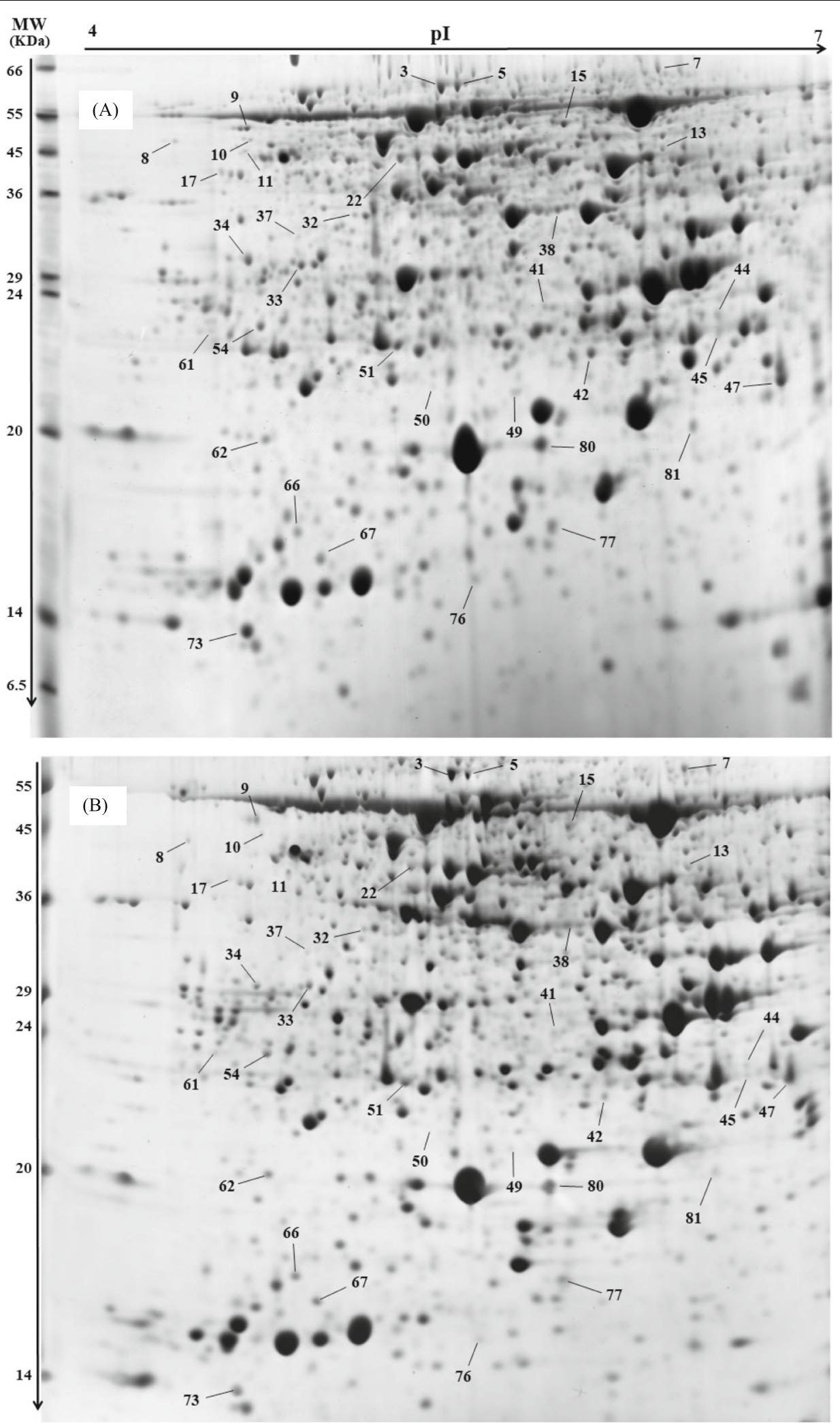

Fig. 2 Representative 2-D photos of chickpea leaf proteins stained by Coomassie blue in the a drought-tolerant (MCC537, T), and $\mathbf{b}$ droughtsensitive (MCC806, S) genotypes. First dimension: $17 \mathrm{~cm}$ IEF strips pH 4-7 linear, second dimension: SDS-PAGE containing 12.5\% (W/v) polyacrylamide. Lines indicate differentially regulated protein spots subjected to LC-MS/MS analysis 
(A)

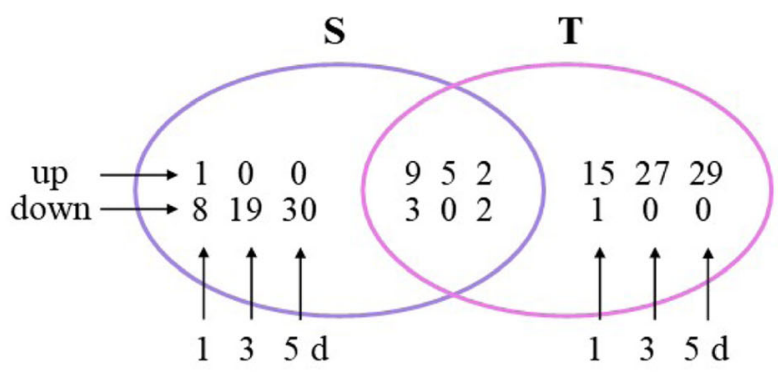

(B)
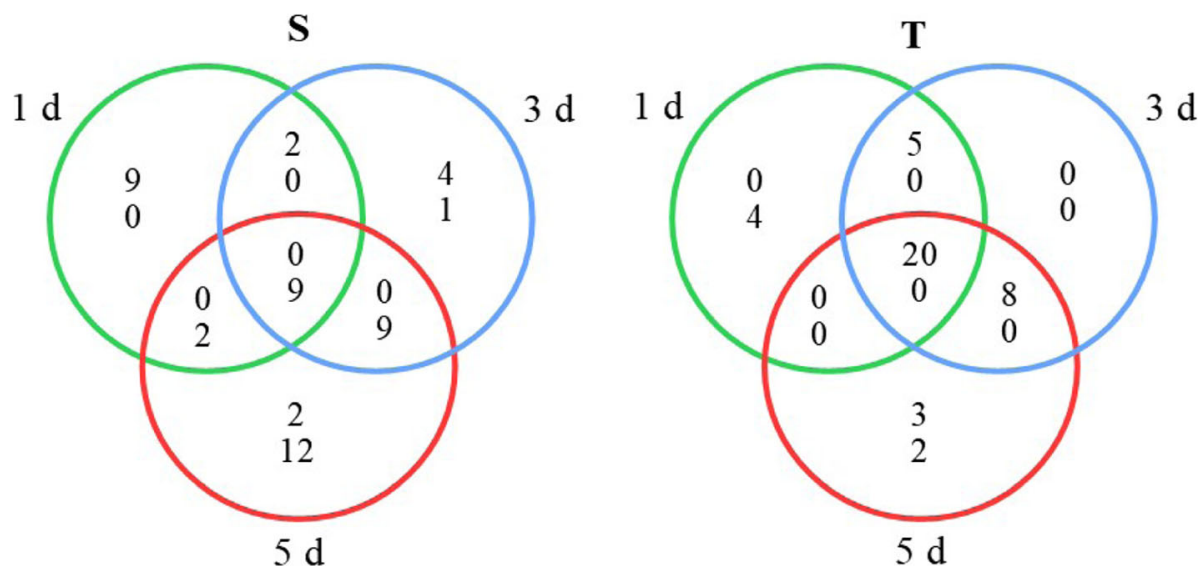

Fig. 3 Venn diagram comparing differentially expressed proteins (DEPs) with controls among sensitive (S) and tolerant (T) genotypes of chickpea after 1, 3, and 5 days (d) of dehydration stress. a Number of genotype-dependent DEPs at each time-point (or shared between). $\mathbf{b}$ Number of time-point-dependent DEPs (or shared between) in each genotype. The up and down arrows indicate the number of increased and decreased DEPs, respectively, relative to the respective controls

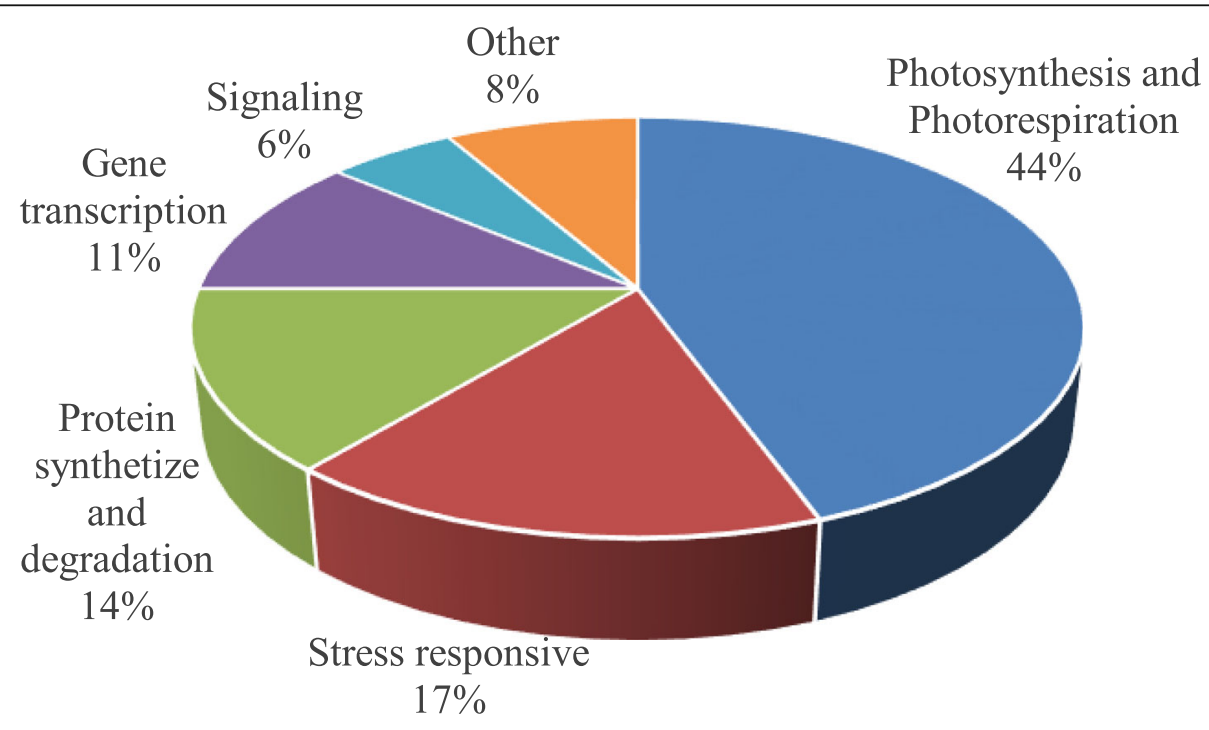

Fig. 4 Functional classification of stress-responsive proteins in chickpea $(n=34)$ 

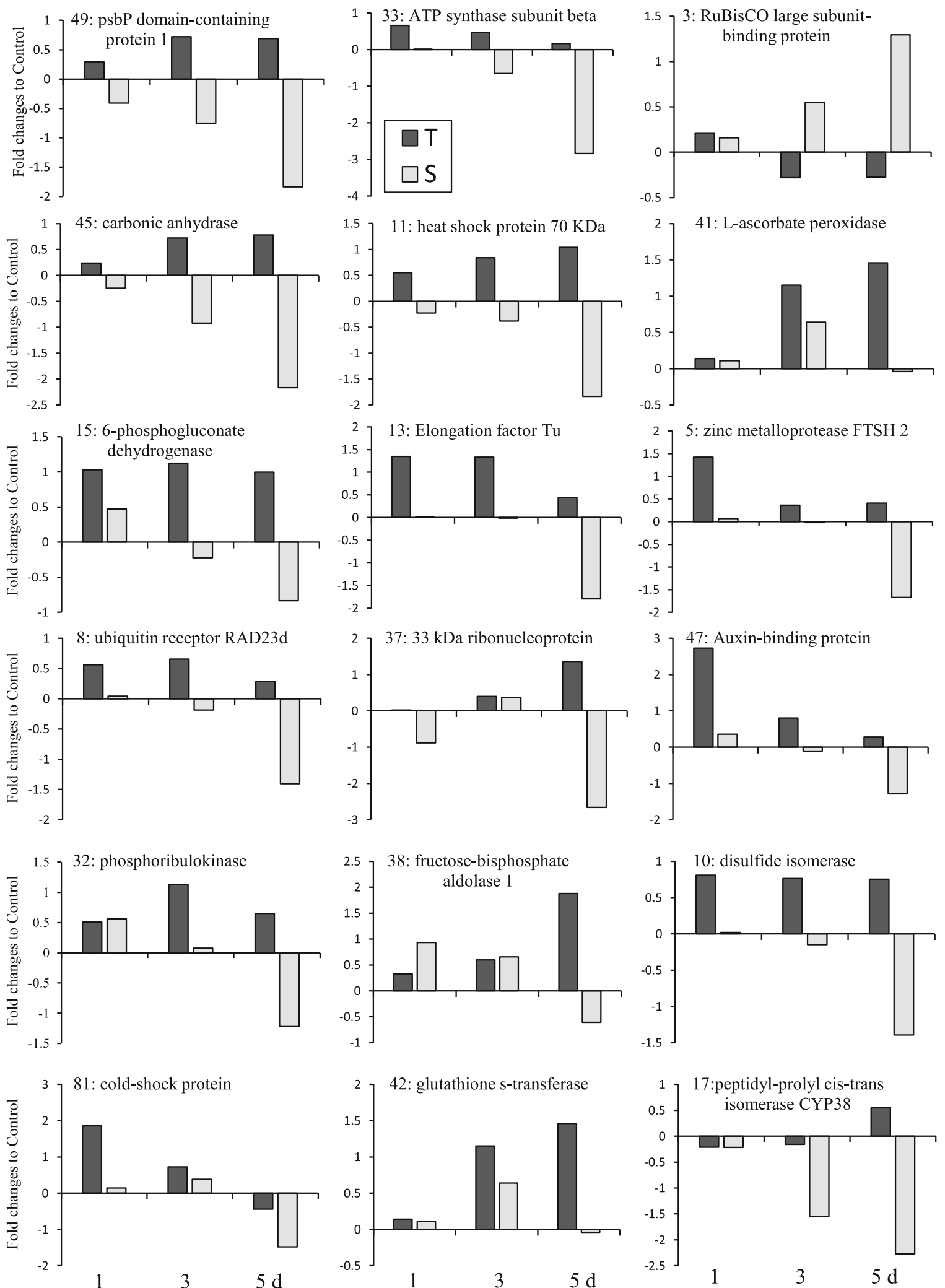

Fig. 5 Fold-changes in the abundance of some important dehydration-responsive proteins, relative to the control, in terms of function and the rate of differential expression between two chickpea genotypes (MCC537, T, and MCC806, S) after 1, 3 and 5 days of dehydration treatments. Numbers before the name of each protein correspond with the spot numbers specified in Table 1 and Fig. 2 
alpha and beta detected in this study were up-regulated in response to dehydration stress in the $\mathrm{T}$ genotype (Fig. 5 ; spot 33). After 5 days of dehydration stress, the subunits of the ATP synthase complex in the $S$ genotype declined $\sim 3$-fold, indicating high regulation of the whole machinery. ATP synthase activity facilitates nonphotochemical quenching, a process that protects the photosynthetic apparatus from light-damage; reductions in its activity have been reported in other species under stressful conditions [54].

RuBisCo (EC 4.1.1.39) accounts for a major portion of soluble leaf proteins (about $30-70 \mathrm{~g} / 100 \mathrm{~g}$ ) and is a key player in photosynthesis. RuBisCo catalyzes carbon metabolism at an early stage of $\mathrm{CO}_{2}$ fixation in photosynthetic eukaryotes and plays a role in phosphoglycolate synthesis, which is re-circulated by photorespiration. Photorespiration drains the pool of sugar substrate (RuBP) and reduces the efficiency of carbon fixation by up to $50 \%$. Thus, the key role of RuBisCo is to suppress oxygenation and improve carboxylation, which is necessary for some important characteristics such as biomass, plant height, and yield in drought-tolerant crop genotypes [55]. In this study, $3 \mathrm{~d}$ and $5 \mathrm{~d}$ of dehydration stress induced RuBisCo subunits in the T genotype (Fig. 5; spot 3). Other enzymes involved in the Calvin cycle, including carbonic anhydrase (Fig. 5; spot 45), phosphoribulokinase (spot 32), and fructose-bisphosphate aldolase 1 (spot 38), increased in abundance in the $\mathrm{T}$ genotype, relative to the control and the $\mathrm{S}$ genotype. These proteins have been associated with abiotic stress tolerance in chickpea, including heat [25] and drought $[19,20]$ stress. In line with earlier reports, our results show that the accumulation of osmo-protectants could be another strategy embraced by the T genotype to cope with dehydration stress by retaining cell turgor pressure [56] and thus maintaining RWC. Moreover, proline can assist in the maintenance of photosynthetic efficiency, cellular redox potential, and antioxidant free radical amounts in thylakoid membranes [45]. The greater stress-dependent proline level and RWC in the T genotype relative to the $\mathrm{S}$ genotype (Fig. 1b) suggests that the $\mathrm{T}$ genotype can moderate its proline content for cell defense and osmotic adjustment to cope with dehydration stress. Other studies have reported proline accumulation in chickpea in response to drought and salinity, especially in tolerant genotypes $[17,46]$. The correlation between enhanced levels of photosynthetic enzymes [55] and proline content may have increased photosynthesis, biomass, and yield more in the $\mathrm{T}$ genotype than the $\mathrm{S}$ genotype under dehydration stress [16].

In this study, six proteins were specifically involved in the dehydration stress response: heat- and cold-shock proteins (spots 11 and 81 ), L-ascorbate peroxidase (spots 41 and 51), superoxide dismutase (spot 77), and glutathione s-transferase (spot 42) (Table 1). Drought stress causes protein dysfunction by denaturation and aggregation [57]. Hence, many HSPs are up-regulated under stress to stabilize proteins and membranes and refold proteins [58]. The induction of HSP70 in the T genotype, relative to the control and the $\mathrm{S}$ genotype (Fig. 5 , spot 11), suggests that protein stabilization and refolding may have increased to cope with dehydration stress. The induction of HSPs has been reported in salt- and water-stressed rice [59], potato [60], and soybean [61].

The cold-shock domain protein is a highly conserved nucleic acid binding domain that may act as an RNAchaperone in the regulation of translation [62], and has been induced in the leaves of rice [63] and roots of wheat [64] under salt stress. It is possible that higher expression of the cold-shock protein (Fig. 5, spot 81) in the $\mathrm{T}$ genotype than the $\mathrm{S}$ genotype during the early stages of dehydration stress facilitated the translation process by removing secondary structures of mRNA and regulating gene expression by dsDNA interaction.

Production of ROS due to stress leads to membrane loss, accompanied by ion leakage, that is harmful to chlorophyll and the photosynthetic apparatus, and diminishes plant productivity [65]. In the present study, a considerable increase of antioxidant and detoxification enzymes in the $\mathrm{T}$ genotype was reflected in higher RWC, reduced EL, and less MDA, suggesting that protection against oxidative stress damage is a principal endurance mechanism in chickpea. In contrast, drought stress had a more negative effect on the $\mathrm{S}$ genotype, with high MDA content and increased EL, which has been associated with enhanced protein degradation and lipid peroxidation [66]. The slight initial decline in MDA content in both genotypes could be due to an increase in unsaturated fatty acids during the first day of stress [42, 43]. The $T$ genotype had higher levels of antioxidant enzymes than the $\mathrm{S}$ genotype, mostly after $3 \mathrm{~d}$ and $5 \mathrm{~d}$ of dehydration stress (Fig. 5, spot 41). Redox homeostasis is maintained in plants by antioxidant enzymes and low molecular-weight osmolytes [67]. Superoxide dismutase (SOD) converts the potentially harmful superoxide radical $\left(\mathrm{O}_{2}^{-}\right)$to molecular oxygen and $\mathrm{H}_{2} \mathrm{O}_{2}$, thus playing an effective role in cell defense and rescue [68].

Glutathione s-transferase is an important detoxification enzyme in the GPX/GST pathway, removing $\mathrm{H}_{2} \mathrm{O}_{2}$ [69]. The GPX/GST pathway, as an alternative mechanism for removing $\mathrm{H}_{2} \mathrm{O}_{2}$, was activated after $5 \mathrm{~d}$ of stress, especially in the $\mathrm{T}$ genotype (1.6-fold), to compensate for reduced expression of ascorbate peroxidase (Fig. 5, spot 42). Time- and genotype-dependent regulation of antioxidants were observed in this study. Similarly, Salekdeh et al. (2002) [70] reported a diverse abundance of antioxidants in rice under drought stress, indicating that their functional state is dependent on subcellular 
location, stress conditions, and genotype. Consistent with our results, tolerant genotypes of soybean [71, 72] and canola [73] had higher expression of superoxide dismutase and ascorbate peroxidase than susceptible genotypes. Thus, it appears that these antioxidants play an essential role in the drought tolerance of the $\mathrm{T}$ genotype. NADPH can be generated through the oxidative pentose pathway and used to prevent oxidative stress [74]. Salt stress induced 6phosphogluconate dehydrogenase in barley leaves [74] and rice shoots [75]. An increased abundance of 6phosphogluconate dehydrogenase (Fig. 5, spot 15) in the $\mathrm{T}$ genotype may have increased NADPH production to supply the required energy for drought tolerance. Based on our results, it is likely that the $\mathrm{T}$ genotype has higher membrane integrity than the $\mathrm{S}$ genotype-as evidenced by its reduced LA and MDA content, higher RWC, and abundance of heat- and cold-shock proteins, L-ascorbate peroxidase, superoxide dismutase, and glutathione s-transferasethereby reducing dehydration stress damage to membranes $[15,17]$ and possibly increasing water-use efficiency.

The protein biogenesis and degradation group accounted for $14 \%$ of the DEPs in the stressed seedlings (Fig. 4). Dehydration stress significantly increased the elongation factor $\mathrm{Tu}$ (Fig. 5, spot 13) level in the $\mathrm{T}$ genotype after $1 \mathrm{~d}$ and $3 \mathrm{~d}$ but significantly decreased it in the $\mathrm{S}$ genotype at $5 \mathrm{~d}$ (Fig. 5). Elongation factors contribute to the initiation and elongation of newly growing peptide chains [76], which may explain why the enhanced biosynthesis or repair of drought-stressed proteins. In this study, the abundance of peptidyl-prolyl cis-trans isomerase CYP38 (Fig. 5; spot 17) and disulfide isomerase (Fig. 5 ; spot 10) increased in the $\mathrm{T}$ genotype, indicating its greater ability for protein biogenesis, folding and stability than the $S$ genotype.

Proteases have essential roles in plants by maintaining protein quality control and degrading specific sets of damaged proteins and other unstructured peptides under stress [77]. The levels of ATPdependent zinc metalloprotease FTSH 2 (spot 5) and ubiquitin receptor RAD23d (spot 8) decreased significantly in the $\mathrm{S}$ genotype at $5 \mathrm{~d}$ (Fig. 5). The reduction in degrading proteins at specific times in this experiment may suggest a reduction in proteolysis of peculiar proteins that may be needed during drought stress. However, the observed differential regulation of distinct components in the protein biogenesis and degradation machinery suggests that a complicated mechanism is involved in controlling protein metabolism under drought stress that depends on time and genotype.
Four identified proteins-ribonucleoproteins (spots 37, 61, 54, and 76)-were classified as gene transcription proteins (Table 1) that are involved in RNA processing [78]. These proteins, which accumulated more in the $\mathrm{T}$ genotype than the $\mathrm{S}$ genotype under dehydration stress (Fig. 5, spot 37), are a regulatory factor in the response of plants to biotic and abiotic stresses through the translation of defense-related genes in the chloroplast [79].

This study identified two dehydration stress-induced proteins involved in signaling-auxin-binding protein ABP19a-like (spot 47) and low molecular-weight phosphotyrosine protein phosphatase (spot 80)-that increased after $1 \mathrm{~d}$ of stress, especially in the T genotype, but decreased after $5 \mathrm{~d}$ of stress, especially in the $\mathrm{S}$ genotype (Fig. 5; spot 47). Auxin is a fundamental hormonal signaling agent in cells, which functions as an integrator for other phytohormones to control plant growth under environmental stress [80]. Our results suggest that dehydration stress enhances the auxin signal transduction pathway in the leaves of chickpea seedlings by increasing the amount of auxin-binding protein during the initial stages of dehydration stress in both genotypes, especially the T genotype, which would alter many metabolic pathways and cellular processes to cope with dehydration stress. This should be validated in further experiments.

\section{Conclusion}

To identify drought-responsive proteins in chickpea, two contrasting genotypes in terms of drought tolerance were compared using some physiological parameters and a proteomic approach. The proteome alterations suggest that the up-regulated proteins, especially those in the $\mathrm{T}$ genotype at $5 \mathrm{~d}$, are associated with photosynthesis, protein metabolism, and signaling, and included ATP synthase subunits, psbP domain-containing protein, carbonic anhydrase, RuBisCo subunits, elongation factor $\mathrm{Tu}$ and disulfide isomerase. These proteins might contribute to alleviating the harmful effect of dehydration stress on chlorophyll biosynthesis, photosynthesis, energy synthesis, and gene expression in chickpea leaves. The major protein differences between the two genotypes emerged in redox homeostasis, particularly Lascorbate peroxidase, superoxide dismutase, and glutathione s-transferase, as well as higher accumulation of other stress-response proteins such as HSPs in the T genotype than the $\mathrm{S}$ genotype. Based on our results, it is likely that the $\mathrm{T}$ genotype has higher membrane integrity than the $\mathrm{S}$ genotype-as evidenced by its reduced LA and MDA content, higher RWC, and abundance of proteins such as heat- and cold-shock proteins, L-ascorbate peroxidase, superoxide dismutase, and glutathione stransferase-which could reduce dehydration stress injuries to membranes and possibly increase water-use efficiency. Up-regulation of the auxin-binding protein 
after $1 \mathrm{~d}$ of stress, especially in the $\mathrm{T}$ genotype, suggests its involvement in the initial stages of the auxin signal transduction pathway and, in turn, its function as a possible integrator for other phytohormones to control plant growth under stress conditions. Overall, the results have offered insight into the proteome dynamics of drought tolerance in chickpea, and a framework for further functional studies on each identified protein.

\section{Supplementary information}

Supplementary information accompanies this paper at https://doi.org/10. 1186/s12864-020-06930-2.

\section{Additional file 1}

\section{Abbreviations}

ECM: Extracellular matrix; ROS: Reactive oxygen species; 2-DE: Twodimensional electrophoreses; MALDI-TOF/TOF: Matrix Assisted Laser Desorption Ionization - Time of Flight; LC-MS/MS: Liquid chromatographymass spectrometry; LEA: Late embryogenesis abundant; HSPs: Heat shock proteins; TCA cycle: Tricarboxylic acid cycle; RWC: Relative water content; FW: Fresh weight; DW: Dry weight; TW: Turgid weight; EL: Electrolyte leakage; MDA: Malondialdehyde; TCA: Trichloroacetic acid; IEF: Isoelectric focusing; DTT: Dithiothreitol; IPG: Immobilized pH gradient; SDS: Sodium dodecyl sulfate; $M_{r}$ : Molecular mass; pl: Isoelectric point; ANOVA: Analysis of variance; DEPS: Differentially expressed proteins; PSI and PSII: Photosystem I and II; RuBisCo: Ribulose 1,5-bisphosphate carboxylase/oxygenase; SOD: Cu/Zn superoxide dismutase

\section{Acknowledgments}

We are grateful to the Institute of Agriculture, UWA for its partial financial and technical support. We also thank Research Center for Plant Sciences and The Research Institute of Biotechnology, FUM.

\section{Authors' contributions}

M.A. designed the experiments, carried out experimental work, analyzed the data, and wrote the manuscript. S.V. assisted in the experimental design, methodology, interpretation of data, and manuscript writing and editing. K.S. helped to perform mass spectrometric analyses and revised the manuscript. All authors read and approved the final manuscript.

\section{Funding}

This work was financially supported by the grants from Ferdowsi University of Mashhad (FUM) and The University of Western Australia (UWA). The funders provided financial support and had no role in the study design, data analysis and interpretation, or manuscript writing

\section{Availability of data and materials}

All the data generated or analyzed during this study are included in this published article.

\section{Ethics approval and consent to participate}

Not applicable.

\section{Consent for publication}

Not applicable.

\section{Competing interests}

The authors declare that they have no competing interests.

\section{Author details}

${ }^{1}$ Research Center for Plant Sciences, Ferdowsi University of Mashhad, Mashhad, Iran. ${ }^{2}$ Plant Biotechnology and Breeding Department, College of Agriculture, Ferdowsi University of Mashhad, Mashhad, Iran. ${ }^{3}$ The UWA Institute of Agriculture, The University of Western Australia, Perth, WA 6001 Australia.
Received: 30 April 2019 Accepted: 20 July 2020

Published online: 29 July 2020

\section{References}

1. Wang $Y$, Frei M. Stressed food-the impact of abiotic environmental stresses on crop quality. Agric Ecosyst Environ. 2011;141(3-4):271-86.

2. Cramer GR, Urano K, Delrot S, Pezzotti M, Shinozaki K. Effects of abiotic stress on plants: a systems biology perspective. BMC Plant Biol. 2011;11(1): 163-76.

3. Hawkesford MJ, Araus JL, Park R, Calderini D, Miralles D, Shen T, Zhang J, Parry MA. Prospects of doubling global wheat yields. Food Energy Secur. 2013;2(1):34-48

4. Bokszczanin $\mathrm{KL}$, Fragkostefanakis $\mathrm{S}$, Bostan $\mathrm{H}$, Bovy A, Chaturvedi $\mathrm{P}$, Chiusano ML, Firon N, lannacone R, Jegadeesan S, Klaczynskid K. Perspectives on deciphering mechanisms underlying plant heat stress response and thermotolerance. Front Plant Sci. 2013;4:315.

5. Chohan A, Raina S. Comparative studies on morphological and biochemical characters of chickpea genotypes under chilling stress. J Environ Biol. 2011; 32:189-94.

6. Jain D, Chattopadhyay D. Analysis of gene expression in response to water deficit of chickpea (Cicer arietinum L.) varieties differing in drought tolerance. BMC Plant Biol. 2010;10(1):24-38.

7. Thudi M, Gaur PM, Krishnamurthy L, Mir RR, Kudapa H, Fikre A, Kimurto P, Tripathi S, Soren KR, Mulwa R. Genomics-assisted breeding for drought tolerance in chickpea. Funct Plant Biol. 2014;41(11):1178-90.

8. Toker C, Llunch C, Tejera N, Serraj R, Siddique K. Abiotic stresses in chickpea breeding and management. In: Yadav SS, Redden RJ, W Chen, Sharma B. Chickpea Breeding and Management. UK: CAB International Publisher; 2007. p. 474-96.

9. Siddique K, O'Connell L. Understanding growth stresses of cool season pulses. Brisbane: Shared Solutions Cropping Manual, Australian Grain Berekua; 2000. p. 12-6.

10. Saxena N, Johansen C, Silim S, Saxena M. In: Singh KBS, M.C, editors Selection for drought and salinity tolerance in cool season food legumes. Chichester: Wiley; 1993. p. 245-70.

11. Leport L, Turner N, French R, Barr M, Duda R, Davies S, Tennant D, Siddique K. Physiological responses of chickpea genotypes to terminal drought in a Mediterranean-type environment. Eur J Agron. 1999;11(3-4):279-91.

12. Faroog M, Gogoi N, Hussain M, Barthakur S, Paul S, Bharadwaj N, Migdadi HM, Alghamdi SS, Siddique KH. Effects, tolerance mechanisms and management of salt stress in grain legumes. Plant Physiol Biochem. 2017; 118(1):199-217.

13. Dossa K, Li D, Wang L, Zheng X, Liu A, Yu J, Wei X, Zhou R, Fonceka D, Diouf D. Transcriptomic, biochemical and physio-anatomical investigations shed more light on responses to drought stress in two contrasting sesame genotypes. Sci Rep. 2017;7(1):8755-69.

14. Jaleel CA, Manivannan P, Wahid A, Farooq M, Al-Juburi HJ, Somasundaram R, Panneerselvam R. Drought stress in plants: a review on morphological characteristics and pigments composition. Int J Agric Biol. 2009;11(1):100-5.

15. Kocheva K, Nenova V, Karceva T, Petrov P, Georgiev G, Börner A, Landjeva S. Changes in water status, membrane stability and antioxidant capacity of wheat seedlings carrying different Rht-B1 dwarfing alleles under drought stress. J Agron Crop Sci. 2014;200(2):83-91.

16. Nenova V, Kocheva K, Petrov P, Georgiev G, Karceva T, Börner A, Landjeva S. Wheat Rht-B1 dwarfs exhibit better photosynthetic response to water deficit at seedling stage compared to the wild type. J Agron Crop Sci. 2014;200(6): 434-43.

17. Petrov P, Petrova A, Dimitrov I, Tashev T, Olsovska K, Brestic M, Misheva S. Relationships between leaf morpho-anatomy, water status and cell membrane stability in leaves of wheat seedlings subjected to severe soil drought. J Agron Crop Sci. 2018;204(3):219-27.

18. Mooney BP, Miernyk JA, Michael Greenlief C, Thelen JJ. Using quantitative proteomics of Arabidopsis roots and leaves to predict metabolic activity. Physiol Plant. 2006;128(2):237-50.

19. Bhushan D, Pandey A, Choudhary MK, Datta A, Chakraborty S, Chakraborty N. Comparative proteomics analysis of differentially expressed proteins in chickpea extracellular matrix during dehydration stress. Mol Cell Proteomics. 2007:6(11):1868-84.

20. Bhushan D, Jaiswal DK, Ray D, Basu D, Datta A, Chakraborty S, Chakraborty N. Dehydration-responsive reversible and irreversible changes in the 
extracellular matrix: comparative proteomics of chickpea genotypes with contrasting tolerance. J Proteome Res. 2011;10(4):2027-46.

21. Pandey A, Chakraborty S, Datta A, Chakraborty N. Proteomics approach to identify dehydration responsive nuclear proteins from chickpea (Cicer arietinum L.). Mol Cell Proteomics. 2008;7(1):88-107.

22. Pandey A, Choudhary MK, Bhushan D, Chattopadhyay A, Chakraborty S, Datta A, Chakraborty N. The nuclear proteome of chickpea (Cicer arietinum L.) reveals predicted and unexpected proteins. J Proteome Res. 2006;5(12): 3301-11.

23. Barua $P$, Lande NV, Subba P, Gayen D, Pinto S, Keshava Prasad T, Chakraborty S, Chakraborty N. Dehydration-responsive nuclear proteome landscape of chickpea (Cicer arietinum L.) reveals phosphorylation-mediated regulation of stress response. Plant Cell Environ. 2019;42(1):230-44.

24. Vessal S, Siddique KH, Atkins CA. Comparative proteomic analysis of genotypic variation in germination and early seedling growth of chickpea under suboptimal soil-water conditions. J Proteome Res. 2012;11(8):4289-307.

25. Parankusam S, Bhatnagar-Mathur P, Sharma KK. Heat responsive proteome changes reveal molecular mechanisms underlying heat tolerance in chickpea. Environ Exp Bot. 2017;141:132-44.

26. Arefian M, Vessal S, Shafaroudi SM, Bagheri A. Comparative analysis of the reaction to salinity of different chickpea (Cicer aretinum L.) genotypes: a biochemical, enzymatic and transcriptional study. J Plant Growth Regul. 2018;37(2):391-402.

27. Arefian M, Vessal S, Malekzadeh-Shafaroudi S, Siddique KH, Bagheri A. Comparative proteomics and gene expression analyses revealed responsive proteins and mechanisms for salt tolerance in chickpea genotypes. BMC Plant Biol. 2019;19(1):300

28. Gautam AK, Gupta N, Srivastava N, Bhagyawant SS. Proteomic analysis of chickpea roots reveal differential expression of abscisic acid responsive proteins. J Food Biochem. 2019;43(7):e12838.

29. Ahmad F, Gaur P, Croser J. Chickpea (Cicer arietinum L.). Genet Resour Chromosome Eng Crop Improv Grain Legumes. 2005;1:185-214.

30. Ganjeali A, Porsa H, Bagheri A. Assessment of Iranian chickpea (Cicer arietinum L.) germplasms for drought tolerance. Agric Water Manag. 2011; 98(9):1477-84

31. Jin S, Chen C, Plant A. Regulation by ABA of osmotic-stress-induced changes in protein synthesis in tomato roots. Plant Cell Environ. 2000;23(1):51-60.

32. Premachandra G, Saneoka H, Ogata S. Cell membrane stability, an indicator of drought tolerance, as affected by applied nitrogen in soyabean. J Agric Sci. 1990;115(1):63-6.

33. Bates LS, Waldren RP, Teare I. Rapid determination of free proline for waterstress studies. Plant Soil. 1973;39(1):205-7.

34. Heath RL, Packer L. Photoperoxidation in isolated chloroplasts: I. kinetics and stoichiometry of fatty acid peroxidation. Arch Biochem Biophys. 1968;125(1): 189-98.

35. Goggin DE, Powles SB, Steadman KJ. Selection for low or high primary dormancy in Lolium rigidum gaud seeds results in constitutive differences in stress protein expression and peroxidase activity. J Exp Bot. 2011;62(3): 1037-47.

36. Bradford MM. A rapid and sensitive method for the quantitation of microgram quantities of protein utilizing the principle of protein-dye binding. Anal Biochem. 1976;72(1):248-54.

37. Candiano G, Bruschi M, Musante L, Santucci L, Ghiggeri GM, Carnemolla B, Orecchia P, Zardi L, Righetti PG. Blue silver: a very sensitive colloidal Coomassie G-250 staining for proteome analysis. Electrophoresis. 2004;25(9):1327-33.

38. Bringans S, Eriksen S, Kendrick T, Gopalakrishnakone P, Livk A, Lock R, Lipscombe R. Proteomic analysis of the venom of Heterometrus longimanus (Asian black scorpion). Proteomics. 2008;8(5):1081-96.

39. Conesa A, Götz S, García-Gómez JM, Terol J, Talón M, Robles M. Blast2GO: a universal tool for annotation, visualization and analysis in functional genomics research. Bioinformatics. 2005;21(18):3674-6.

40. Luo M, Zhao Y, Wang Y, Shi Z, Zhang P, Zhang Y, Song W, Zhao J. Comparative proteomics of contrasting maize genotypes provides insights into salt-stress tolerance mechanisms. J Proteome Res. 2017;17(1):141-53.

41. Subba P, Kumar R, Gayali S, Shekhar S, Parveen S, Pandey A, Datta A, Chakraborty S, Chakraborty N. Characterisation of the nuclear proteome of a dehydration-sensitive cultivar of chickpea and comparative proteomic analysis with a tolerant cultivar. Proteomics. 2013;13(12-13):1973-92.

42. Mafakheri A, Siosemardeh A, Bahramnejad B, Struik P, Sohrabi Y. Effect of drought stress on yield, proline and chlorophyll contents in three chickpea cultivars. Aust J Crop Sci. 2010;4(8):580.
43. Mantri NL, Ford R, Coram TE, Pang EC. Transcriptional profiling of chickpea genes differentially regulated in response to high-salinity, cold and drought. BMC Genomics. 2007;8(1):303.

44. Varshney RK, Hiremath PJ, Lekha P, Kashiwagi J, Balaji J, Deokar AA, Vadez V, Xiao Y, Srinivasan R, Gaur PM. A comprehensive resource of drought-and salinity-responsive ESTs for gene discovery and marker development in chickpea (Cicer arietinum L.). BMC Genomics. 2009;10(1):523.

45. Varshney RK, Mohan SM, Gaur PM, Gangarao N, Pandey MK, Bohra A, Sawargaonkar SL, Chitikineni A, Kimurto PK, Janila P. Achievements and prospects of genomics-assisted breeding in three legume crops of the semi-arid tropics. Biotechnol Adv. 2013;31(8):1120-34.

46. Varshney RK, Pazhamala L, Kashiwagi J, Gaur PM, Krishnamurthy L, Hoisington D. Genomics and Physiological Approaches for Root Trait Breeding to Improve Drought Tolerance in Chickpea (Cicer arietinum L.). In: Costa de Oliveira A, Varshney R, editors. Root Genomics. Berlin, Heidelberg: Springer; 2011. p. 233-50

47. Meng F, Luo Q, Wang Q, Zhang X, Qi Z, Xu F, Lei X, Cao Y, Chow WS, Sun G. Physiological and proteomic responses to salt stress in chloroplasts of diploid and tetraploid black locust (Robinia pseudoacacia L.). Sci Rep. 2016;6: 23098-113.

48. Andersson U, Heddad M, Adamska I. Light stress-induced one-helix protein of the chlorophyll a/b-binding family associated with photosystem I. Plant Physiol. 2003;132(2):811-20.

49. Roveda-Hoyos G, Fonseca-Moreno LP. Proteomics: a tool for the study of plant response to abiotic stress. Agronomía Colomb. 2011;29(2):412-22.

50. Kargul J, Barber J. Photosynthetic acclimation: structural reorganisation of light harvesting antenna-role of redox-dependent phosphorylation of major and minor chlorophyll a/b binding proteins. FEBS J. 2008;275(6):1056-68.

51. Yabuta S, Ifuku K, Takabayashi A, Ishihara S, Ido K, Ishikawa N, Endo T, Sato F. Three PsbQ-like proteins are required for the function of the chloroplast NAD(P) H dehydrogenase complex in Arabidopsis. Plant Cell Physiol. 2010; 51(6):866-76.

52. Bagheri R, Bashir H, Ahmad J, labal M, Qureshi MI. Spinach (Spinacia oleracea L. ) modulates its proteome differentially in response to salinity, cadmium and their combination stress. Plant Physiol Biochem. 2015;97:235-45.

53. Ye J, Zhang Z, Long H, Zhang Z, Hong Y, Zhang X, You C, Liang W, Ma H, Lu P. Proteomic and phosphoproteomic analyses reveal extensive phosphorylation of regulatory proteins in developing rice anthers. Plant J. 2015;84(3):527-44

54. Kohzuma K, Cruz JA, Akashi K, Hoshiyasu S, Munekage YN, Yokota A, Kramer DM. The long-term responses of the photosynthetic proton circuit to drought. Plant Cell Environ. 2009;32(3):209-19.

55. Wang N, Zhao J, He X, Sun H, Zhang G, Wu F. Comparative proteomic analysis of drought tolerance in the two contrasting Tibetan wild genotypes and cultivated genotype. BMC Genomics. 2015;16(1):432-51.

56. Bhatnagar-Mathur P, Vadez V, Devi MJ, Lavanya M, Vani G, Sharma KK. Genetic engineering of chickpea (Cicer arietinum L.) with the P5CSF129A gene for osmoregulation with implications on drought tolerance. Mol Breed. 2009;23(4):591-606.

57. Waters ER, Lee GJ, Vierling E. Evolution, structure and function of the small heat shock proteins in plants. J Exp Bot. 1996:47(3):325-38.

58. Wang W, Vinocur B, Shoseyov O, Altman A. Role of plant heat-shock proteins and molecular chaperones in the abiotic stress response. Trends Plant Sci. 2004;9(5):244-52.

59. Xu D, Duan X, Wang B, Hong B, Ho T-HD WR. Expression of a late embryogenesis abundant protein gene, HVA1, from barley confers tolerance to water deficit and salt stress in transgenic rice. Plant Physiol. 1996;1 10(1): 249-57.

60. Aghaei K, Ehsanpour AA, Komatsu S. Proteome analysis of potato under salt stress. J Proteome Res. 2008;7(11):4858-68.

61. Aghaei K, Ehsanpour A, Shah A, Komatsu S. Proteome analysis of soybean hypocotyl and root under salt stress. Amino Acids. 2009;36(1):91-8.

62. Karlson D, Nakaminami K, Toyomasu T, Imai R. A cold-regulated nucleic acid-binding protein of winter wheat shares a domain with bacterial cold shock proteins. J Biol Chem. 2002;277(38):35248-56.

63. Dooki AD, Mayer-Posner FJ, Askari H, Zaiee AA, Salekdeh GH. Proteomic responses of rice young panicles to salinity. Proteomics. 2006;6(24):6498507.

64. Peng Z, Wang M, Li F, Lv H, Li C, Xia G. A proteomic study of the response to salinity and drought stress in an introgression strain of bread wheat. Mol Cell Proteomics. 2009;8(12):2676-86. 
65. Camejo D, Jiménez A, Alarcón JJ, Torres W, Gómez JM, Sevilla F. Changes in photosynthetic parameters and antioxidant activities following heat-shock treatment in tomato plants. Funct Plant Biol. 2006;33(2):177-87.

66. Szklarczyk D, Franceschini A, Wyder S, Forslund K, Heller D, Huerta-Cepas J Simonovic M, Roth A, Santos A, Tsafou KP. STRING v10: protein-protein interaction networks, integrated over the tree of life. Nucleic Acids Res. 2015;43(1):447-52.

67. Gill SS, Tuteja N. Reactive oxygen species and antioxidant machinery in abiotic stress tolerance in crop plants. Plant Physiol Biochem. 2010;48(12): 909-30.

68. Fadzilla NM, Finch RP, Burdon RH. Salinity, oxidative stress and antioxidant responses in shoot cultures of rice. J Exp Bot. 1997;48(2):325-31.

69. Zhang H, Han B, Wang T, Chen S, Li H, Zhang Y, Dai S. Mechanisms of plant salt response: insights from proteomics. J Proteome Res. 2011;11(1):49-67.

70. Salekdeh GH, Siopongco J, Wade LJ, Ghareyazie B, Bennett J. Proteomic analysis of rice leaves during drought stress and recovery. Proteomics. 2002; 2(9):1131-45.

71. Ma H, Song L, Shu Y, Wang S, Niu J, Wang Z, Yu T, Gu W, Ma H. Comparative proteomic analysis of seedling leaves of different salt tolerant soybean genotypes. J Proteome. 2012;75(5):1529-46.

72. Pi E, Qu L, Hu J, Huang Y, Qiu L, Lu H, Jiang B, Liu C, Peng T, Zhao Y. Mechanisms of soybean roots' tolerances to salinity revealed by proteomic and phosphoproteomic comparisons between two cultivars. Mol Cell Proteomics. 2016;15(1):266-88.

73. Sun XE, Feng XX, Li C, Zhang ZP, Wang L. Study on salt tolerance with YHem1 transgenic canola (Brassica napus). Physiol Plant. 2015;154(2):223-42.

74. Abdalla K. Proteomics approach for identifying salt stress related proteins in barley leaves. Egypt J Genet Cytol. 2016;42(1):195-204.

75. Huang J, Zhang H, Wang J, Yang J. Molecular cloning and characterization of rice 6-phosphogluconate dehydrogenase gene that is up-regulated by salt stress a. Mol Biol Rep. 2003;30(4):223-7.

76. Wan X-Y, Liu J-Y. Comparative proteomics analysis reveals an intimate protein network provoked by hydrogen peroxide stress in rice seedling leaves. Mol Cell Proteomics. 2008;7(8):1469-88.

77. García-Lorenzo M. The role of proteases in plant development. Umeå: VMCKBC, Umeå University; 2007.

78. Wang X, Cai X, Xu C, Wang Q, Dai S. Drought-responsive mechanisms in plant leaves revealed by proteomics. Int J Mol Sci. 2016;17(10):1706.

79. Lv D-W, Subburaj S, Cao M, Yan X, Li X, Appels R, Sun D-F, Ma W, Yan Y-M. Proteome and phosphoproteome characterization reveals new response and defense mechanisms of Brachypodium distachyon leaves under salt stress. Mol Cell Proteomics. 2013. https://doi.org/10.1074/mcp.M113.030171.

80. Jaillais $\mathrm{Y}$, Chory J. Unraveling the paradoxes of plant hormone signaling integration. Nat Struct Mol Biol. 2010;17(6):642-5.

\section{Publisher's Note}

Springer Nature remains neutral with regard to jurisdictional claims in published maps and institutional affiliations.

Ready to submit your research? Choose BMC and benefit from:

- fast, convenient online submission

- thorough peer review by experienced researchers in your field

- rapid publication on acceptance

- support for research data, including large and complex data types

- gold Open Access which fosters wider collaboration and increased citations

- maximum visibility for your research: over $100 \mathrm{M}$ website views per year

At BMC, research is always in progress.

Learn more biomedcentral.com/submissions 